RESEARCH REPORT

\title{
Physical violence, self rated health, and morbidity: is gender significant for victimisation?
}

\author{
V Sundaram, K Helweg-Larsen, B Laursen, P Bjerregaard
}

J Epidemiol Community Health 2004;58:65-70

See end of article for authors' affiliations

....................

Correspondence to: Vanita Sundaram, National Institute of Public Health, Svanemøllevej 25, 2100-Denmark: vsu@niph.dk

Accepted for publication 30 June 2003

\begin{abstract}
Study objective: To analyse gender differences in associations between physical violence and self rated health and self reported morbidity among a random sample of adults in Denmark.

Design and setting: Two questions on self rated health and self reported morbidity respectively, were obtained from a cross sectional national health interview survey conducted among 12028 adults (16 years + ) in Denmark in 2000. A question on six different forms of physical violence was obtained from a supplementary self administered questionnaire given to the same sample. The reporting period for experienced physical violence was the past 12 months and for morbidity symptoms, the past 14 days. Main results: Men aged 16-24 years were significantly more likely to have experienced violence than women $(\mathrm{OR}=3.2,95 \% \mathrm{Cl}=2.3$ to 4.2$)$. Female victims of physical violence were significantly more likely to rate their health as poor $(\mathrm{OR}=2.02,95 \% \mathrm{Cl}=1.41$ to 2.89$)$ and to report anxiety $(\mathrm{OR}=2.14,95 \%$ $\mathrm{Cl}=1.35$ to 3.37$)$, depression $(\mathrm{OR}=2.36,95 \% \mathrm{Cl}=1.55$ to 3.60$)$, and stomach ache $(\mathrm{OR}=1.58,95 \%$ $\mathrm{Cl}=1.01$ to 2.47 ) than female non-victims. Male victims of physical violence were only significantly more likely to report stomach ache $(\mathrm{OR}=1.73,95 \% \mathrm{Cl}=1.03$ to 2.89$)$ than male non-victims.

Conclusions: Associations between physical violence and poor self rated health and self reported morbidity were found to be significant for women, but not for men. It is probable that gender differences in experiences of violence, as well as gender differences in health related self perception, contribute to a gender specific process of victimisation. Improved knowledge about the relation between gender specific violence and victimisation as a gender specific consequence is essential for targeting violence prevention.
\end{abstract}

$\mathrm{V}$ iolence is increasingly being recognised as a public health problem that has long term human and economic costs. ${ }^{12}$ An increasing amount of research is beginning to offer a global picture of the extent of violence. The magnitude, nature, and health impact of violence differ greatly for men and women. Men and women's respective experiences of violence are characterised by widely differing power and gender relations, inherent in the different settings, contexts, mechanisms, and perpetrators of violence. ${ }^{34}$

Most violence experienced by men is perpetrated by men and primarily occurs in public spaces. ${ }^{56}$ Violence usually occurs as isolated incidents, rather than repeated, ongoing abuse and men's violence towards each other is accepted and normalised as a "natural" aspect of socially constructed masculine behaviour. ${ }^{7}$ Importantly, the perpetrator-victim relationship among men is much more rarely an intimate one, compared with violence against women. ${ }^{58}$ Consequently, the likelihood of a dependence relationship between the victim and abuser is less. However, it should be noted here that intimate partner violence is presumably underreported by men, particularly in homosexual relationships. ${ }^{9-11}$

Violence against women comprises a wide range of abuses, including collective violence, interpersonal violence perpetrated by strangers, and intimate partner violence. ${ }^{212}$ Violence against women has been distinguished from other forms of violence as "gender based violence", ${ }^{13}$ rooted in gender inequality and the perpetuation of male power and control. ${ }^{14}$ WHO estimates that at least one in five women has been physically or sexually assaulted by a man at some time in their lives. ${ }^{15}$ Interpersonal violence against women is primarily perpetrated by a male intimate partner and occurs within the confines of the home. ${ }^{316}$ The violence is "hidden" from public view and when it becomes visible, it is often dismissed as a private, family affair. ${ }^{17}$ Intimate partner violence is often repeated, continuous, and used as a means by which to control the woman's actions and behaviour. ${ }^{17}$ The physical abuse coupled with social and economic inequalities often render the woman "powerless" and dependent and the male abuser powerful. Women in violent relationships may also have responsibility for children, which may further prevent them from leaving their abuser. Additionally, societal and legal norms often render it difficult for the woman to seek and obtain help and support to leave her abuser. ${ }^{18}$

Interpersonal violence against women has numerous physical and mental health effects, ranging from immediately visible lesions and severe physical injuries to long term effects such as poor health status and poor quality of life, including loss of social networks and diminished ability to work. ${ }^{19} 20$ Violence is estimated to be responsible for one of every five healthy days of life lost to women of reproductive age. ${ }^{1}$ Both the physical and the mental stress caused by violence can lead to chronic health problems that persist long after the abuse has ended, ${ }^{21-24}$ including chronic headache and back pain, fainting, seizures, cardiac symptoms and chest pain. ${ }^{19}$ Choking and severe blows to the head can also have critical neurological consequences. ${ }^{19} 22$ The negative physical and psychological effects of physical violence are also salient when violence is low severity-that is, pushing and grabbing or threats, as compared with hitting, slapping or choking. ${ }^{25}$ Women with current violence of any severity are more likely to have a history of substance misuse and to have a substance misusing partner, thereby putting them at an increased risk for physical and mental health problems. ${ }^{25}$

A few studies have researched the health consequences of interpersonal violence among men. Experienced intimate partner violence and stalking have both been associated with poor health for men, including depression, injury, substance misuse, and chronic mental illness. ${ }^{26}{ }^{27}$ Additionally, experienced violence among men has been associated with 
depressive symptoms, increased alcohol use and diminished social support. ${ }^{28}$ The association remained significant and constant regardless of the perpetrator relation, indicating that victimisation by persons other than a partner is also associated with poor health. Sexual abuse has also been associated with mental health problems for both genders and is associated with increased alcohol consumption, substance misuse, and self harm particularly among men. ${ }^{29-31}$

A recent Greenlandic study analysed associations between physical and sexualised violence and health for both genders. The study found that women were significantly more likely to report experiencing violence and sexual abuse and the associations between violence and poor health were stronger for women than for men. ${ }^{32}$ No similar Scandinavian studies have been conducted.

The overall aim of this study was to examine the gendered process of health related victimisation as a consequence of violence. Victimisation is related both to self perception and to external imposition of victim identity. The social constructions of gender and sexuality that define masculinity as necessarily dominant, aggressive and powerful and femininity as weak, passive and subordinate are integral to the gendered labelling of victims. ${ }^{33}$ If men are expected to be masculine and thereby powerful, dominant, and in control, they cannot be discursively produced as victims - the antithesis of masculinity.

Therefore, it can be argued that the gendering of victimhood discursively produces women as victims in relation to men. In terms of interpersonal violence, women are named as victims. This status defines the woman as object of the man's actions, as weak, powerless. Men are named as actors, "doers" in relation to their violence against women and towards each other. Gender specific forms of violence and the gendered imposition of victim status presumably interact and differentially influence men and women's self perception. This may relate to assessment and perception of own vulnerability, capabilities and resources consequent to violence, as well as own wellbeing and health status.

The specific aim of this study is therefore to examine whether gendered victimisation as a consequence of violence manifests itself in gender differences in self perceived poor health and morbidity among survivors of violence. We recognise that health related victimisation is one of many facets of gendered victimisation.

\section{METHODS}

The health data used in this study were obtained from the Danish national health interview survey, conducted among the adult population ( 16 years + ) in 2000 . The data primarily describe the incidence and distribution of health and morbidity in the adult population. This includes factors that are of significance to health status, such as health behaviour, life style, health risks at work, and external health resources, such as social networks or healthcare services.

The survey was implemented by face to face interview, conducted by trained interviewers in the respondents' homes. Additionally, the survey encompassed a self administered questionnaire with questions about violence and sexual abuse that were to be answered by the respondent following the interview, and then to be returned by mail. The questions on violence, including perpetrator information were identical to those included in the Greenlandic study. ${ }^{33}$ The study was approved by the Danish Central Scientific Ethical Committee and written informed consent was obtained from participants. The sample consisted of 16684 adult persons randomly selected from the Central Population Register in Denmark. Of these, $12028(72 \%)$ participants were interviewed and given the self administered questionnaire.
The question about physical violence asked about five different forms of violence, ${ }^{34}$ previously tested in the Canadian Violence Against Women survey ${ }^{35}$ - experienced during the past 12 months and ever. The original question (English translation) was:

- Have you as an adult, experienced one or more of the following forms of physical violence within the past 12 months or ever?

(a) Being pushed, shaken or lightly struck

(b) Being kicked, struck with a fist or an object

(c) Being thrown against furniture, walls, down stairs or similar

(d) Being strangled, assaulted with knife or firearm

(e) Other form of violence, specify

The questionnaire included separate questions on the perpetrator of both physical and sexualised violence. The questionnaire also included separate questions on sexualised violence, which were not included in this study.

In this study, the five measures of physical violence were dichotomised to a single variable: experienced violence within the past 12 months-yes or no. A positive response to one or more of the violence measures and to having experienced violence during the past 12 months thus defined a violence victim.

Two indicators of health from the interview survey were used in this study: self rated health as a broad indicator of self perceived wellbeing, and four measures of self reported morbidity. Respondents were asked the following question about their own health:

- How would you rate your health in general? (excellent/ good/fair/poor/very poor).

This measure of self assessed health was dichotomised to indicate good (excellent-good) versus poor (fair-poor-very poor).

The question regarding morbidity was:

- Have you experienced any of the below mentioned symptoms of pain or discomfort within the past 14 days?

The symptoms were limited to those that have been empirically associated with experienced physical abuse..$^{36-38}$ They were (a) anxiety/nervousness/restlessness/uneasiness, (b) melancholy/depression/unhappiness, (c) stomach ache, (d) headache.

\section{Statistical analysis}

Statistical analysis was performed using SPSS software version 11.0 for Windows and SAS System version 8.2. Using SPSS, gender disaggregated cross tabulations for violence and age groups were performed. Using SAS, odds ratios (OR) were calculated to estimate associations between violence, poor self rated health and morbidity for both genders. Potential confounders were identified on the basis of biological or behavioural interference with the associations between violence and health. OR were thus adjusted for age, socioeconomic status and marital status in logistic regression models. Statistical significance was determined using the 95\% confidence interval (CI) level.

\section{RESULTS}

The self administered questionnaire was answered by an approximately equal number of men $(n=4975)$ and women $(n=5483)$ yielding an overall response rate of $87 \%$ of those that had received the questionnaire $(85 \%$ for men, $88 \%$ for women). This constituted $62 \%$ of the original random sample. Table 1 shows gender differences in reported 
Table 1 Reported incidence of physical violence in the past 12 months

\begin{tabular}{lll}
\hline Age groups & Male victims \% $(95 \% \mathrm{Cl})$ & Female victims $\%(95 \% \mathrm{Cl})$ \\
\hline $16-24$ years & $28.4(24.8$ to 32.1$)$ & $11.1(8.9$ to 13.8$)$ \\
$25-44$ years & $n=171$ & $n=75$ \\
& $5.7(4.6$ to 6.9$)$ & $4.6(3.8$ to 5.7$)$ \\
45 years and above & $n=95$ & $n=92$ \\
& $1.4(1.0$ to 2.0$)$ & $1.4(1.0$ to 1.9$)$ \\
& $n=37$ & $n=38$ \\
\hline
\end{tabular}

Victims of violence, by gender and age groups. Crude prevalence percentages. Danish National Health and Morbidity Survey 2000.

experience of physical violence by age groups. Men aged 1624 years were significantly more likely to have experienced violence than women. Table 2 presents the prevalence of poor self rated health and morbidity for victims of physical violence and non-victims by gender and age groups. Table 3 presents the odds ratios (OR) for correlations between experienced physical violence, poor self rated health, and morbidity for both genders. Common cold, a comparatively widespread disease, was tested as a control for its prevalence among victims of violence, compared with non-victims. Adjusted OR show that overall, associations between violence and poor self rated health and morbidity were significant for women for all conditions except headache and common cold. Male victims of violence were only significantly more likely to report stomach ache than male non-victims.

\section{DISCUSSION}

Two important results were found in this study. Firstly, men aged 16-24 years were significantly more likely to have experienced violence than women. Secondly, the associations between physical violence and poor self rated health and morbidity were significant for women, but not for men. Only stomach ache was significantly associated with violence among men. This manifestation of gender specific victimisation is presumably in large part attributable to the gender specific nature of violence against women, including the intimate perpetrator relation and private, isolated context of violence.

The questionnaire used in this study did include a separate question on the perpetrator of physical violence and violent threats. However, the response rate on this question was too low for valid conclusions to be drawn. This is an important limitation of the study. However, data indicate that women primarily report being abused or threatened by a former spouse, while for men the perpetrator is primarily a stranger or in the category "other".

An association between violence and headache was not found for either gender, possibly because headache is already a comparatively common symptom in the general adult population..$^{30}$ Reporting frequency may not increase significantly after experienced violence. There was no association between violence and depression among men, possibly because certain feminised illnesses such as depression are reported less among men generally ${ }^{41}{ }^{42}$ and experienced

Table 2 Prevalence of poor self rated health and morbidity for victims of physical violence and non-victims, by gender and age groups

\begin{tabular}{|c|c|c|c|c|c|}
\hline \multirow[b]{2}{*}{ Men } & \multirow{2}{*}{$\frac{\text { Poor self rated health \% }}{(95 \% \mathrm{Cl})}$} & \multirow{2}{*}{$\frac{\text { Anxiety \% }}{(95 \% \mathrm{CI})}$} & \multirow{2}{*}{$\frac{\text { Depression \% }}{(95 \% \mathrm{Cl})}$} & \multirow{2}{*}{$\begin{array}{l}\text { Stomach ache \% } \\
(95 \% \mathrm{Cl})\end{array}$} & \multirow{2}{*}{$\begin{array}{l}\text { Headache \% } \\
(95 \% \mathrm{Cl})\end{array}$} \\
\hline & & & & & \\
\hline \multicolumn{6}{|l|}{$16-24$} \\
\hline Victims & $\begin{array}{l}9.4(5.5 \text { to } 14.8) \\
n=16\end{array}$ & $\begin{array}{l}1.8(0.4 \text { to } 5.2) \\
n=3\end{array}$ & $\begin{array}{l}2.9(0.9 \text { to } 6.6) \\
n=5\end{array}$ & $\begin{array}{l}4.1(1.7 \text { to } 8.3) \\
n=7\end{array}$ & $\begin{array}{l}18.1(12.6 \text { to } 24.7) \\
n=31\end{array}$ \\
\hline Non-victims & $\begin{array}{l}7.4(5.1 \text { to } 10.3) \\
n=32\end{array}$ & $\begin{array}{l}2.1(1.0 \text { to } 3.9) \\
n=9\end{array}$ & $\begin{array}{l}3.7(2.1 \text { to } 5.9) \\
n=16\end{array}$ & $\begin{array}{l}4.4(2.7 \text { to } 6.8) \\
n=19\end{array}$ & $\begin{array}{l}16.0(12.7 \text { to } 19.8) \\
n=69\end{array}$ \\
\hline \multicolumn{6}{|l|}{$25-44$} \\
\hline Victims & $\begin{array}{l}22.1(14.2 \text { to } 31.8) \\
n=21\end{array}$ & $\begin{array}{l}6.3(2.3 \text { to } 13.2) \\
n=6\end{array}$ & $\begin{array}{l}7.4(3.0 \text { to } 14.7) \\
n=7\end{array}$ & $\begin{array}{l}9.5(4.4 \text { to } 17.3) \\
n=9\end{array}$ & $\begin{array}{l}17.9(10.8 \text { to } 27.1) \\
n=17\end{array}$ \\
\hline Non-victims & $\begin{array}{l}13.6(11.9 \text { to } 15.4) \\
n=214\end{array}$ & $\begin{array}{l}3.2(2.4 \text { to } 4.2) \\
n=50\end{array}$ & $\begin{array}{l}4.1(3.2 \text { to } 5.2) \\
n=65\end{array}$ & $\begin{array}{l}4.0(3.1 \text { to } 5.1) \\
n=63\end{array}$ & $\begin{array}{l}16.5(14.7 \text { to } 18.4) \\
n=260\end{array}$ \\
\hline \multicolumn{6}{|l|}{$45+$} \\
\hline Victims & $\begin{array}{l}27.0(13.8 \text { to } 44.1) \\
n=10\end{array}$ & $\begin{array}{l}10.8(3.0 \text { to } 25.4) \\
n=4\end{array}$ & $\begin{array}{l}13.5 \text { (4.5 to } 28.7) \\
n=5\end{array}$ & $\begin{array}{l}13.5 \text { (4.5 to } 28.7) \\
n=5\end{array}$ & $\begin{array}{l}16.2(6.2 \text { to } 32.0) \\
n=6\end{array}$ \\
\hline Non-victims & $\begin{array}{l}24.4(22.7 \text { to } 26.1) \\
n=621\end{array}$ & $\begin{array}{l}3.7(3.0 \text { to } 4.5) \\
n=95\end{array}$ & $\begin{array}{l}4.4(3.6 \text { to } 5.3) \\
n=113\end{array}$ & $\begin{array}{l}4.6(3.8 \text { to } 5.5) \\
n=117\end{array}$ & $\begin{array}{l}9.7(8.6 \text { to } 10.9) \\
n=246\end{array}$ \\
\hline \multicolumn{6}{|l|}{$\begin{array}{l}\text { Women } \\
16-24\end{array}$} \\
\hline Victims & $\begin{array}{l}21.3(12.7 \text { to } 32.3) \\
n=16\end{array}$ & $\begin{array}{l}10.7(4.7 \text { to } 20.0) \\
n=8\end{array}$ & $\begin{array}{l}17.3(9.5 \text { to } 27.8) \\
n=13\end{array}$ & $\begin{array}{l}17.3(9.5 \text { to } 27.8) \\
n=13\end{array}$ & $\begin{array}{l}37.3(26.4 \text { to } 49.3) \\
n=28\end{array}$ \\
\hline Non-victims & $\begin{array}{l}9.6(7.4 \text { to } 12.3) \\
n=57\end{array}$ & $\begin{array}{l}6.7(4.8 \text { to } 9.0) \\
n=40\end{array}$ & $\begin{array}{l}6.4(4.6 \text { to } 8.7) \\
n=38\end{array}$ & $\begin{array}{l}9.2(7.0 \text { to } 11.8) \\
n=55\end{array}$ & $\begin{array}{l}32.8(29.0 \text { to } 36.4) \\
n=196\end{array}$ \\
\hline \multicolumn{6}{|l|}{$25-44$} \\
\hline Victims & $\begin{array}{l}21.7(13.8 \text { to } 31.5) \\
n=20\end{array}$ & $\begin{array}{l}12.0(6.1 \text { to } 20.5) \\
n=11\end{array}$ & $\begin{array}{l}13.0(6.9 \text { to } 21.6) \\
n=12\end{array}$ & $\begin{array}{l}9.8(4.6 \text { to } 17.8) \\
n=9\end{array}$ & $\begin{array}{l}39.1 \text { (29.1 to } 49.8) \\
n=36\end{array}$ \\
\hline Non-victims & $\begin{array}{l}14.3(12.7 \text { to } 16.0) \\
n=269\end{array}$ & $\begin{array}{l}5.3(4.3 \text { to } 6.4) \\
n=99\end{array}$ & $\begin{array}{l}6.5(5.4 \text { to } 7.7) \\
n=122\end{array}$ & $\begin{array}{l}6.8(5.7 \text { to } 8.0) \\
n=129\end{array}$ & $\begin{array}{l}31.1(29.0 \text { to } 33.2) \\
n=588\end{array}$ \\
\hline $\begin{array}{l}\text { 45+ } \\
\text { Victims }\end{array}$ & $\begin{array}{l}39.5(24.1 \text { to } 56.6) \\
n=15\end{array}$ & 15.8 (6.0 to 31.3 ) & 13.2 (4.4 to 28.2 ) & 7.9 (1.7 to 21.4$)$ & 18.4 (7.7 to 34.3$)$ \\
\hline Non-victims & $\begin{array}{l}n=15 \\
28.8(27.1 \text { to } 30.6) \\
n=758\end{array}$ & $\begin{array}{l}n=6 \\
7.1(6.1 \text { to } 8.2) \\
n=186\end{array}$ & $\begin{array}{l}n=5 \\
7.2(6.2 \text { to } 8.3) \\
n=190\end{array}$ & $\begin{array}{l}n=3 \\
6.2(5.3 \text { to } 7.2) \\
n=163\end{array}$ & $\begin{array}{l}n=7 \\
15.8(14.4 \text { to } 17.3) \\
n=416\end{array}$ \\
\hline
\end{tabular}

Crude percentages. Danish National Health and Morbidity Survey 2000. 
Table 3 Correlations between physical violence, poor self rated health, and morbidity

\begin{tabular}{|c|c|c|c|c|}
\hline & \multicolumn{2}{|l|}{ Men } & \multicolumn{2}{|l|}{ Women } \\
\hline & \multicolumn{2}{|l|}{ Crude } & \multicolumn{2}{|l|}{ Crude } \\
\hline & OR $(95 \% \mathrm{Cl})$ & Adjusted & OR $(95 \% \mathrm{Cl})$ & Adjusted \\
\hline $\begin{array}{l}\text { Poor self rated } \\
\text { health }\end{array}$ & 0.78 (0.57 to 1.07 ) & 1.31 (0.91 to 1.89 ) & 1.23 (0.89 to 1.70$)$ & $2.02(1.41$ to 2.89$)$ \\
\hline Anxiety & $1.28(0.72$ to 2.29$)$ & 1.53 (0.81 to 2.87$)$ & 2.04 (1.33 to 3.15$)$ & 2.14 (1.35 to 3.37$)$ \\
\hline Depression & $1.34(0.80$ to 2.23$)$ & 1.40 (0.80 to 2.44$)$ & $2.33(1.56$ to 3.48$)$ & 2.36 (1.55 to 3.60 ) \\
\hline Stomach ache & $1.63(1.03$ to 2.60$)$ & 1.73 (1.03 to 2.89$)$ & 1.91 (1.24 to 2.95 ) & 1.58 (1.01 to 2.47 ) \\
\hline Headache & $1.50(1.11$ to 2.05$)$ & $1.16(0.83$ to 1.61$)$ & $1.73(1.29$ to 2.32$)$ & 1.27 (0.94 to 1.72$)$ \\
\hline Common cold & 1.61 (1.18 to 2.19$)$ & 1.25 (0.89 to 1.74$)$ & 1.55 (1.08 to 2.21$)$ & $1.12(0.78$ to 1.62$)$ \\
\hline
\end{tabular}

Victims of violence compared with non-victims as baseline (crude odds ratios (OR) and OR adjusted for age, socioeconomic status, and marital status). Danish National Health and Morbidity Survey 2000.

violence does not change this pattern. We can assume that most violence experienced by women in this study was perpetrated by known men and that most violence against men was perpetrated by male strangers or acquaintances. The power imbalance and abuse that characterises intimate partner violence probably has a far more severe psychological impact than group violence or public, socially normalised violence. Male abusers have the physical, and often financial and emotional power to control and confine the woman, isolate her from her social networks, her family, and other resources. This immense power differential does not characterise public, male violence and may therefore largely explain the lacking association between violence and depression for men in our study.

The 12 month prevalence of violence reported particularly by women aged 25-44 years, was relatively low compared with other studies. ${ }^{2} 1944$ The wide range in prevalence estimates $^{45-48}$ may be attributable to difference in levels of violence between settings, as well as differences in study design, ${ }^{19}$ including the definitions of abuse used, interviewer training, and cultural differences in respondent's willingness to disclose sensitive information. ${ }^{216}$ Moreover, abused women frequently invalidate and normalise their experiences

\section{Key points}

- Violence is increasingly being recognised as a public health problem. The magnitude, nature and health impact of violence differ greatly for men and women. Research on the gender specific process of victimisation among survivors of violence is limited. This study examined how health related victimisation is gendered among survivors of physical violence.

- Young men were significantly more likely to experience violence than women.

- Associations between physical violence, poor self rated health and self reported morbidity were significant for women, but not men.

- It is probable that gender specific experiences of violence and gender differences in health perceptions interact and contribute to a gender specific process of victimisation. Future work should address the relation between violence, power, and gender in relation to victimisation as a gender specific process. This knowledge could be used in developing gender specific and prevention strategies, for example, psychological self defence tactics for women, which deconstruct oppressive power gender relations - that is, male equates to powerful, female equates to weak. of violence. ${ }^{49} 50$ Many prevalence studies now include emotional, physical and sexualised violence in their definitions of partner abuse to reflect the complexity of the abuse. ${ }^{19} 49$ This difference in inclusiveness may explain differences in prevalence between studies, and the relatively low prevalence in our study.

This study did not include sexualised violence in its analysis of interpersonal violence. We note that rape and other forms of sexual abuse rarely occur on their own in the context of intimate partner violence, they are often coupled with physical abuse and vice versa. ${ }^{216} 19$ The prevalence of violence for women in this study would likely be higher, had physical and sexualised violence been analysed as part of the same phenomenon. Additionally, it must be acknowledged that a complete picture of the violence-health association will not be obtained for those persons that have experienced both forms of violence.

It can be assumed that the self reported morbidity symptoms are specifically correlated to experienced violence as adjusted OR show no associations between violence and the control symptom, cold. However, causation between experienced violence and poor health cannot be shown by cross sectional data. Victims of violence may, at baseline, present other health problems than persons who have not experienced violence. ${ }^{23}$ This may present a significant bias to the correlation between experienced violence and poor health. ${ }^{51}$ However, studies have shown that risk factors for exposure to, and injury from intimate partner violence hinge on characteristics of the perpetrator, rather than the abused woman. These include unemployment, history of arrest, and substance misuse. ${ }^{5253}$

A strength of this study was that it used nationally representative data, covering all ages $\geqslant 16$ years and it achieved a comparatively high response rate. Generally, there has been a decreasing response rate in most European health interview surveys. ${ }^{55}$ Recent surveys on violence against women based upon self administered questionnaires have achieved comparatively low response rates. ${ }^{56}{ }^{57}$ Of those who answered our self administered questionnaire, $98 \%$ of male respondents and $97 \%$ of female respondents answered the violence questions.

A recent study found that even a two month time lapse has an effect on recall bias, such that prevalence rates are significantly underestimated. ${ }^{58}$ In our study, the effect of recall bias was greatly reduced, as we focused on physical violence experienced within the past year and morbidity symptoms experienced within the past 14 days.

However, this study relied on self perceived health and morbidity symptoms as an outcome measure. The measures have been previously tested. ${ }^{59}{ }^{60}$ The validity of self rated health, in terms of objectivity and predictive value has been questioned. Self rated health is often equated with subjective health, in contrast with medically defined health. ${ }^{61}$ However, 


\section{Policy implications}

- The results of this study strengthen the importance of improving knowledge about the relation between gender specific experiences of violence and victimisation as a gender specific consequence.

- The results can be implemented in developing evidence based violence prevention strategies that account for the gender specific mechanisms underlying violence, including its form and function. The following initiatives, which follow WHO's recent recommendations* could be implemented by the Ministries of Health, Education and Gender Equality:

- Implementation of screening for violence victims at hospitals and general practices, as female victims of violence are significantly more likely to report poor health and morbidity than non-victims.

- Public awareness campaigns and education targeted at young men and women about the damaging consequences of using and accepting violence, as well as risk factors for exposure to violence.

- General education starting at primary school level, based on gender aware initiatives teaching self reliance, self awareness, and self respect to children and young adults, which may prevent gendered patterns of exposure to physical and sexualised violence.

as has been pointed out, doctors' evaluations of health are rarely objective as they rely upon the personal perceptions of the doctor in question. ${ }^{61}$ The concept of objectivity postulated and defined by quantitative research has been criticised by feminist researchers and sociologists. ${ }^{5062} 63$ They have argued that the notion of objectivity has been based on male experiences and definitions of what constitutes worthy research. Similarly, the use of surveys to obtain universal knowledge has been criticised, as surveys treat all people as being equal actors and therefore do not reflect the patriarchal reality in which data are gathered..$^{50}$ This has often obscured women's experiences in quantitative, "objective" data. ${ }^{65} 66$

Sen has criticised self reported morbidity as being an extremely misleading measure of ill health, as self perception may be influenced by the subject's social experience. ${ }^{66}$ Social experience is inevitably gendered and therefore, we can presume that gender differences may exist in perceptions of health and illness, which are determined by and interact with gender specific experiences and socially imposed gendered identifications, including masculinity/femininity and victim status. Just as gender specific life events ${ }^{67}{ }^{68}$ differentially influence women and men's frames of reference, ${ }^{61}$ so will gender specific experiences of violence. Studies show that women do rate their health as worse than men in corresponding age groups. ${ }^{6768}$ Self rated health has been reported as a valid predictor of morbidity and future health care use. ${ }^{6-72}$ We therefore view social experience and self rated health as especially relevant for analysing health related victimisation as a gendered process, because background factors for men and women will differ greatly and influence the frame of reference in which they rate their own health and perceive their own wellbeing.

This study found associations between physical violence, poor self rated health, and self reported morbidity for

* Resolution WHA56.24 "Implementing the recommendations of the World report on violence and health", 28 May 2003. women, but not men. It is probable that gender differences in experiences of violence and health related self perception, contribute to a gender specific process of victimisation. Improved knowledge of the mechanisms underlying violence is essential for developing gender specific prevention strategies. $^{73}$ Future work should address the mechanisms of violence that lead to gender specific victimisation, including gender specific forms and functions of violence, and the role of social gender constructions in experiences of violence, power, and victimisation.

\section{Authors' affiliations}

V Sundaram, K Helweg-Larsen, B Laursen, P Bjerregaard, National Institute of Public Health, Denmark

Funding: Financial support was received from the Nordic Research Academy's (NorFa) Gender and Violence 2000-2004 program, the Egmont Fund and Daphne-a European Commission program to combat violence against children, young people and women.

Conflicts of interest: none declared.

\section{REFERENCES}

1 Heise LL, Pitanguy J, Germain A. Violence against women: the hidden health burden, World Bank discussion papers (225). Washington, DC: World Bank, 1994.

2 Watts C, Zimmermann C. Violence against women: global scope and magnitude. Lancet 2002;359:1232-7.

3 Dobash RE, Dobash R. Violence against wives: a case against the patriarchy. London: Open Books, 1980.

4 Buss DM, Malamuth NM. Sex, power, conflict: evolutionary and feminist perspectives. Oxford: Oxford University Press, 1996.

5 Jewkes R. Violence against women: an emerging health problem. Int Clin Psychopharmacol 2000;15:S37-45.

6 Christensen E, Koch-Nielsen I. Vold ude og hiemme [Violence in public and at home]. Copenhagen: Reproset, Oct 1992.

7 Brown DB, Hogg R. Policing patriarchy. Australian Left Peview Oct 1992:8-9.

8 Dobash RE, Dobash R. Women, violence and social change. London: Routledge, 1992

9 Waldner-Haugrud LK, Gratch LV. Sexual coercion in gay/lesbian relationships: descriptives and gender differences. Violence and Victims 1997; 12:87-98.

10 Burke LK, Follingstad DR. Violence in lesbian and gay relationships: theory, prevalence and correlational factors. Clin Psychol Rev 1999;19:487-512.

11 Cruz JM, Firestone JM. Exploring violence and abuse in gay male relationships. Violence and Victims 1998;13:159-73.

12 World Health Organisation. World report on violence and health. Geneva: World Health Organisation, 2002.

13 Economic and Social Council. Report of the Working Group on Violence Against Women. Vienna: United Nations, 1992.

14 United Nations Population Fund (UNFPA). Promoting gender equality http:// www.unfpa.org/gender/violence.htm (accessed 1 May 2003).

15 World Health Organisation. Violence against women. Geneva: WHO/FRD/ WHD, 1998.

16 Jewkes R. Intimate partner violence: causes and prevention. Lancet 2002;359: 1423-9.

17 Bograd M. Feminist perspectives on wife abuse. An introduction. In: Yll̈ K, Borgrad M, eds. Feminist perspectives on wife abuse. Newbury Park: Sage, 1980.

18 Lees S. Carnal knowledge: rape on trial. London: H Hamilton, 1996.

19 Campbell JC. Health consequences of intimate partner violence. Lancet 2002;359:1331-6.

20 Sundaram V, Helweg-Larsen K. Correlations between domestic violence, selfrated health and work-related quality of life. 3rd International conference on women, work and health, Stockholm, 2-5 June 2002: No TuW13:6.

21 Ratner PA. The incidence of wife abuse and mental health status in abused wives in Edmonton, Alberta. Can J Public Health 1993;84:246-9.

22 McCauley J, Kern DE, Kolodner K, et al. The "battering syndrom": prevalence and clinical characteristics of domestic violence in primary internal medicine practices. Ann Intern Med 1995; 123:737-46.

23 Diaz-Olavarrieta C, Campbell J, Garcia de la Cadena C, et al. Domestic violence against patients with chronic neurologic disorders. Arch Neurol 1999;56:681-5.

24 Leserman J, Li Z, Drossman DA, et al. Selected symptoms associated with sexual and physical abuse history among female patients with gastrointestinal disorders: the impact on subsequent health care visits. Psychol Med 1998;28:417-25

25 McCauley J, Kern DE, Kolodner K, et al. Relation of low-severity violence to women's health. J Gen Intern Med 1998;13:687-91.

26 Coker AL, Davis KE, Arias I, et al. Physical and mental health effects of intimate partner violence for men and women. Am J Prev Med 2002;23:260-8.

27 Davis KE, Coker AL, Sanderson M. Physical and mental health effects of being stalked for men. Violence and Victims 2002;17:429-43. 
28 Porcerelli JH, Cogan R, West PP, et al. Violent victimisation of women and men: physical and psychiatric symptoms. J Am Board Fam Pract 2003; 16:32-9.

29 Coxell A, King M, Mezey G, et al. Lifetime prevalence, characteristics and associated problems of non-consensual sex in men: cross-sectional survey. BMJ 1999;318:846-50.

30 Gold SN, Lucenko BN, Elhai JD, et al. A comparison of psychological/ psychiatric symptamology of women and men sexually abused as children. Gender differences in symptoms of adolescents reporting sexual assault. Child Abuse Negl 1999;23:683-92.

31 Moncrieff J, Drummond DC, Candy B, et al. Sexual abuse in people with alcohol problems. A study of the prevalence of sexual abuse and its relationship to drinking behaviour. Br J Psychiatry 1996;169:355-60

32 Curtis $\mathrm{T}$, Larsen FB, Helweg-Larsen $\mathrm{K}$, et al. Violence, sexual abuse and health in Greenland. International Journal of Circumpolar Health 2002;61:109-22.

33 Ronkainen S. Genderless gender as victimizing context: the Finnish case. In: Gender and violence in the Nordic Countries. Conference report. Copenhagen: TemaNord, 2002.

34 Straus MA, Smith C. Family patterns and primary prevention of family violence. Trends Health Care Law Ethics 1993;8:17-25.

35 Dekeseredy WD, Schwartz DM. Women abuse on campus: results from the Canadian national survey. Sage series on violence against women (5). Thousand Oaks, CA: Sage, 1997.

36 Fikree FF, Bhatti LI. Domestic violence and mental health: correlations and conundrums within and across cultures. Soc Sci Med 1997;45:1161-76.

37 Coker AL, Smith PH, Bethea L, et al. Physical health consequences of physical and psychological intimate partner violence. Arch Fam Med 2000;9:451-7.

38 Sutherland C, Bybee D, Sullivan C. The long-term effects of battering on women's health. Womens Health 1998:4:41-70.

39 Bassols Farres A, Bosch-Llonch F, Campillo-Grau M, et al. An epidemiologic study of headache and its treatment in the general population of Catalonia. Rev Neurol 2002:34:901-8.

40 Boardman HF, Thomas E, Croft PR, et al. Epidemiology of headache in an English district. Cephalalgia 2003;23:129-37.

41 Cheng C. Gender-role differences in susceptibility to the influence of support availability on depression. J Pers 1999:67:439-67.

42 Unger DG, Jacobs SB. Couples and chronic obstructive airway diseases: the role of gender in coping and depression. Womens Health 1995;1:237-55.

43 Mazza D, Dennerstein L, Ryan V. Physical, sexual and emotional violence against women: a general practice-based prevalence study. Med J Aust 1996:164:14-17.

44 Hegarty KL, Bush R. Prevalence and associations of partner abuse in women attending general practice: a cross-sectional survey. Aust NZ J Public Health 2002;26:437-42.

45 Jones AS, Campbell JC, Schollenberger J, et al. Annual and lifetime prevalence of partner abuse in a sample of female $\mathrm{HMO}$ enrollees. Womens Health Issues 1999:6:295-305.

46 Dearwater SR, Coben JH, Nah G, et al. Prevalence of domestic violence in women treated at community hospital emergency department. JAMA 1998;480:433-8

47 Heise L, Ellsberg M, Gottemoeller M. Ending violence against women: population reports, Vol 27, no 4. Baltimore: John Hopkins University, School of Public Health, 1999

48 Hegarty K, Roberts G. How common is domestic violence against women? The definition of partner abuse in prevalence studies. Aust N Z J Public Health 1998;22:49-54.

49 Kelly L, Regan L, Burton S. Defending the indefensible? Quantitative feminist research. In: Hinds H, Phoenix A, Stacey J, eds. Working outside women's studies. Lewes: The Falmer Press, 1992.
50 Westmarland $\mathrm{N}$. The quantitative/qualitative debate and feminist research: a subjective view of objectivity. Forum: Qualitative Social Research http:// www.qualitative-research.net/fqs-texte/1-01/1-01westmarland-e.htm (accessed 8 Feb 2003).

51 Helweg-Larsen K, Kruse M. Violence against women and consequent health problems. A register based study. Scand J Pub Health 2003;31:51-7.

52 Kyraciou DN, Anglin E, Taliaferro E, et al. Risk factors for injury to women from domestic violence against women. N Engl J Med 1999;341:1892-8.

53 Grisso JA, Schwarz DF, Hirschinger N, et al. Violent injuries amongst women in an urban area. N Engl J Med 1999;341:1899-905.

54 Clarke R, Breeze E, Sherliker $P$, et al. Design, objectives and lessons from a pilot 25-year follow-up resurvey of survivors in the Whitehall study of London civil servants. J Epidemiol Community Health 1998;52:364-9.

55 Cox CS, Rothwell ST, Madans JH, et al. Plan and operation of the NHANES I Epidemiologic Follow up Study 1987. Vital Health Stat I 1992;27:1-190.

56 Lundgren E, Heimer G, Westerstrand J, et al. Slagen Dam. Umeå: Åströms Tryckeri, 2001.

57 Heiskanen M, Piispa M. Faith, hope and battering. Helsinki: Statistics Finland, 1998

58 Jenkins P, Earle-Richardson G, Slingerland DT, et al. Time dependent memory decay. Am J Ind Med 2002;41:98-101.

59 National Institute of Public Health, Denmark. Danish National Health and Morbidity Survey. Copenhagen: National Institute of Public Health, 1994.

60 Bjerregaard P, Curtis T, Senderovitz F, et al. Levevilkår, livsstil og helbred in Grønland [Living conditions, lifestyle and health in Greenland]. Copenhagen: Danish Institute for Clinical Epidemiology, 1995

61 Bjorner JB, Kristensen TS, Orth-Gomér K, et al. Self rated health: a usefu concept in research, prevention and clinical medicine. Stockholm: Swedish Council for Planning and Coordination of Research, 1996.

62 Bernard J. Women, wives, mothers. Chicago: Aldine, 1975.

63 Smith D. Women's perspective as a radical critique of sociology. Sociological Inquiry 1974;44:7-13.

64 Graham H. Do her answers fit his questions? Women and the survey method. In: Gamarnikov E, Morgan D, Purvis J, eds. The public and the private. London: Heinemann, 1983.

65 Oakley A. Science, gender and women's liberation: an argument against postmodernism. Women's Studies International Forum 1998;21:133-46.

66 Stanley L, Wise S. Breaking out again. London: Routledge, 1993.

66 Sen A. Health: perception versus observation. BMJ 2002;324:860-1.

67 Ministry of Health, New Zealand. Taking the pulse-the 1996/97 New Zealand Health Survey. Wellington: 1999.

68 World Health Organisation, Department for Reproductive Health. Violence against women. Technical paper. http://www.who.int/reproductive-health/ publications (accessed 23 Apr 2003).

69 Kaplan GA, Camacho T. Perceived health and mortality: a nine-year followup of the human population laboratory cohort. Am J Epidemiol 1983:117:292-304

70 Maddox G, Douglass E. Self-assessment of health: a longitudinal study of elderly subjects. J Health Soc Behav 1973;14:87-3.

71 Ren A Okubo T, Takahashi K. Health-related worries, perceived health status and health care utilization. Journal of University of Occupational and Environmental Health, Japan 1994; 16:287-99.

72 Weinberger M, Darnell J, Tierney W, et al. Self-rated health as a predictor of hospital admission and nursing home placement in elderly public housing tenants. Am J Public Health 1986;76:457-9.

73 WHO Task Force on Violence and Health. Violence and Health. Geneva: WHO, 1999 